\title{
En refleksion over universitetsbibliotekets fremtidsperspektiv anno $2009^{1}$
}

\author{
Af Michael Cotta-Schønberg
}

\begin{abstract}
Artiklen undersøger udviklingstendenserne hen imod digitale dokumenter, herunder såvel tendenserne $i$ forlagenes udbud som i bibliotekernes anskaffelser og i brugernes benyttelse. Vurderingen er at Københavns Universitetsbibliotek inden for 5 år stort set vil vare ophørt med at købe trykte tidsskrifter, at det inden for 20 år er ophørt med at købe trykte bøger og at hele den eksisterende trykte litteratur i samlingerne vare erstattet af digitale udgaver inden for 30 år. Brugerne finder information på mange måder, og bibliotekets katalog og hjemmeside er ikke deres primore søgeredskab. Forskningsbibliotekerne konkurrerer både med de specialiserede bibliografiske systemer og med de generelle søgemaskiner, og synes at vare ved at tabe kampen. Artiklen diskutere i dette perspektiv hvilke mulige funktioner forskningsbibliotekerne kan varetage, herunder udvikling af søgesystemer, etablering af studiemiljø, personlig service og bruger-undervisning, forskningsregistrering, etablering af repositories, dataforvaltning og digitalisering af universiteters informationsressourcer. Hvis det lykkes bibliotekerne at hage sig fast til formidlingen af digitale videnressourcer til universitetet kan de overleve som institution. Hvis ikke forsvinder en vardifuld institution, der har tjent civilisationen vel i århundreder, men hvis tid er omme, fordi andre løsninger tjener en ny tid bedre.
\end{abstract}

Michael Cotta-Schønberg er vicedirektør ved Det KongeligeBibliotek,mcs@kb.dk.

\section{Indledning}

Forleden mistede jeg 127 science fiction bøger i en sporvogn i Düsseldorf. Jeg var på vej hjem fra en morgentur i svømmehallen, og de gled bare ud af frakkelommen på mig, uden at jeg opdagede det.

Mit vågne publikum undrer sig allerede nu over, hvordan man kan have 127 bøger i en frakkelomme, og næsten inden jeg nu får sagt det, har I gættet, at det selvfølgelig drejer sig om bøger lagret på et ebogslæseapparat!

For mig selv var det en vigtig aha-oplevelse: den betød for alvor, at e-bøger ikke længere er fremtid, men nutid, og oven i købet så banal nutid, at de ikke bare er noget man tager med i sporvogne, men også noget man glemmer i sporvogne.

Når vi i dag beskæftiger os med forskningsbibliotekernes fremtid, skal vi måske gøre os klart, at fremtiden ikke altid er den fjerne horisont langt der ude, men at den nogen gange er tættere på, medens den andre gange fortaber sig, usikkert, i det fjerne.

Det handler måske om, at vi ikke forholder os til fremtiden som en stor abstrakt størrelse, men til bestemte konkrete begivenheder eller forhold, som tegner fremtiden for os. Ser vi dem klart og tydeligt, rykker fremtiden tæt på, ser vi dem uklart og utydeligt, rykker den længere væk. I dag har jeg besluttet at blive nede på jorden og forholde mig konkret til tingene, således som de tegner sig for mig nu. 
Det er jo ikke, fordi jeg selv længere har en stor personlig aktie i bibliotekernes fremtid, men fordi der i disse år skal træffes beslutninger, som har rækkevidde ind i fremtiden, og som jeg har personligt ansvar for peger i den rigtige strategiske retning.

Disse beslutninger vedrører f.eks.:

- skal vi satse på store samlinger på åbne hylder eller på studiemiljø for de studerende?

- hvor hurtigt og hvor meget skal vi omfordele anskaffelsesbudgetterne fra trykte til elektroniske ressourcer?

- hvor mange personaleressourcer skal vi satse på traditionelle biblioteksprocesser gearet til trykte medier, og hvor mange på andre og nye serviceformer?

- i hvilket omfang kan vi tillade os at kassere trykte bøger og tidsskrifter?

- Hvilke typer medarbejdere skal vi ansætte?

Sådanne problemer - som jeg går ud fra vi alle sammen har - bør ikke løses adhoc og separat, men ud fra overordnede ideer om, hvor vi er på vej hen. Der er desværre ikke nogen autoritativ facitliste, der er faktisk kun store spørgsmål.

Af disse stiller jeg mig som bibliotekschef i dag følgende:

- Forsvinder de trykte medier fra universitetsbibliotekerne?

- Hvor er lånerne på vej hen?

- Overtager forlagene universitetsbibliotekernes funktion vedrørende litteraturforsyning?

- Kan universitetsbibliotekernes andre funktioner sikre vores overlevelse som serviceorganisation?

\section{Forsvinder de trykte medier fra universitets- bibliotekerne?}

Jeg understreger, at spørgsmålet IKKE vedrører, hvordan brugerne læser litteratur, men KUN om der lagres trykt litteratur i universitetsbibliotekerne. Mastereksem-plaret af alle informationsmedier vil have digital form og har det vel allerede i dag, MEN brugerne bestemmer helt selv, hvilket format de vil læse i, og hvordan de vil opbevare deres eksemplar: Skal det være i form at print, der ligner bøger, og er indbundet i oaseged med guldtryk, så får de det, er en elektronisk fil nok, så får de det. Men spørgsmålet er altså ikke, om brugerne læser bøger på en skærm eller ej, men om litteraturen fortsat vil blive lagret $\mathrm{i}$ universitetsbiblioteker? Jeg opdeler dette spørgsmål i to:

- et om tidsskrifter

- og et om bøger

\subsection{Tidsskrifter}

Vi skal se på udbuddet af tidsskrifter, anskaffelsen og benyttelsen, således som det tegner sig i et konkret bibliotek, nemlig Københavns Universitetsbibliotek (KUB), nu også kaldet KUBIS²/KB.

\subsubsection{Udbud}

Udbudssiden er karakteriseret af følgende forhold:

Der er i de sidste 10 år foregået en betydelig koncentration af fagtidsskriftproduk-tionen på få, store kommercielle forlag

- med store økonomiske ressourcer,

- betydelige investeringsformåen

- og med stor fare for monopolisering (f.eks. Elsevier, men ikke kun)

Hertil kommer, at de lærde selskaber og foreninger i vidt omfang overlader deres tidsskrifter til kommercielle forlag.

De kommercielle forlag har i høj grad pushet udviklingen af digitale fagtidsskrifter med det resultat, at stort set alle betydningsfulde fagtidsskrifter i dag findes i elektronisk format. Der er selvfølgelig undtagelser: de fleste små skandinaviske forlag har vanskeligheder med at gå over til digitale publiceringsplatforme, og vi er nødt til at have deres tidsskrifter, ikke så meget fordi de er vigtige for faget som helhed men fordi de vigtige for skandinaviske forskere.

Mange forlag holder stadig liv i de trykte udgaver ved siden af de elektroniske. På en forlagskonference i Boston sidste år, spurgte vi fra de store universitetsbibliotekers side om hvorfor forlagene stadig udgiver de trykte udgaver, og dermed fordyrer hele publikationsprocessen. Vi fik det overraskende svar, at det sandelig ikke er forlagenes kop te, det er fordi der er så mange små biblioteker og privatabonnenter, der slet ikke er interesserede i store elektroniske tidsskriftporteføljer, men er fuldstændig tilfredse med 
små samlinger af f.eks. 100 trykte tidsskrifter. Så det var sandelig bibliotekernes skyld!

\subsubsection{Anskaffelse}

Det var udbudssiden. På anskaffelsessiden har KUB i dag de vigtigste store licenser. Fig. 1 illustrerer udviklingen i anskaffelsen af elektroniske tidsskrifter vs. trykte.

\section{Fig.1 - Tidsskriftanskaffelsertil KUBIS/KB / kr. 2006-2009}

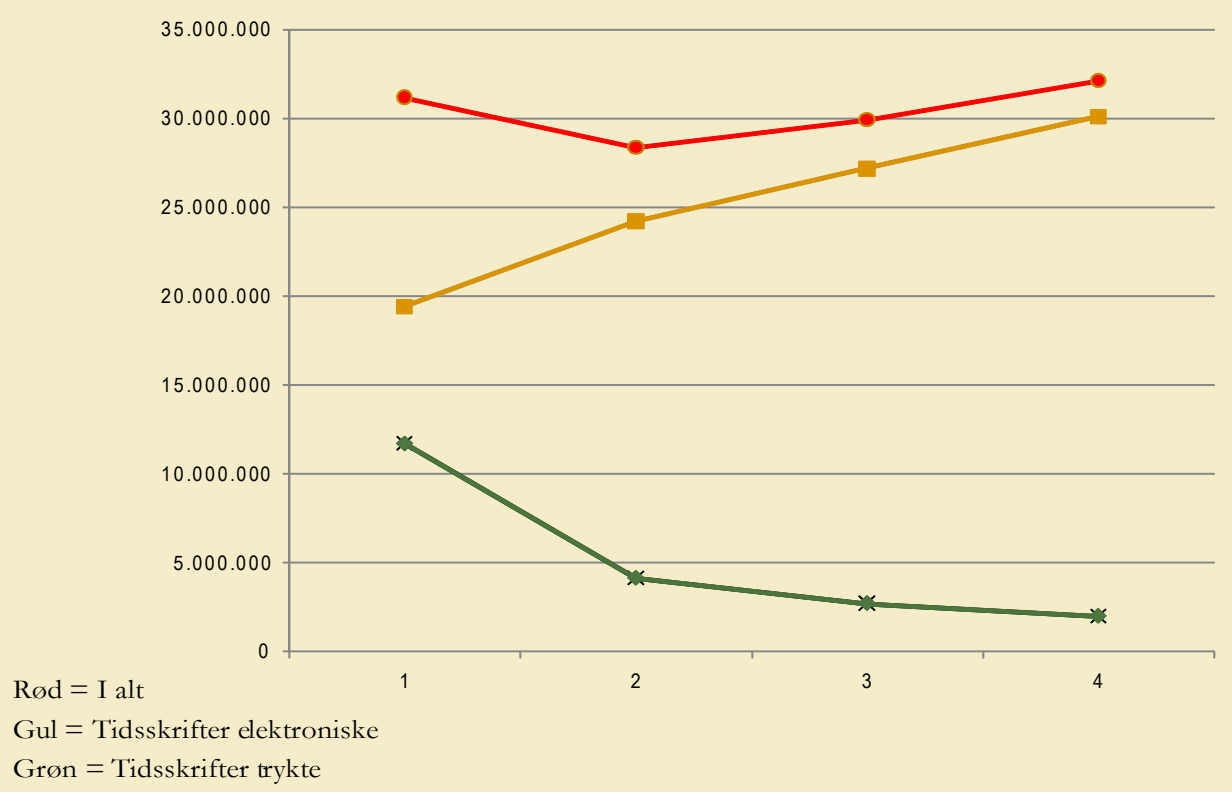

Som man ser af denne figur, udgjorde de trykte tidsskrifter allerede i 2006 kun 1/3 af det samlede anskaffelsesbudget. I 2009-budgettet var denne andel faldet til 1/15 del.

\subsubsection{Benyttelse}

Med hensyn til benyttelsen har jeg desværre ikke statistikdata for den samlede benyttelse af trykte tidsskrifter ved KUB. Jeg har dog data for fremtagningen af tidsskrifter til udlån og kopiering ved Det Natur- og Sundhedsvidenskabelige Fakultetsbibliotek, og da tidsskriftbenyttelsen på dette fagområde generelt er meget betydelig, er tallene en fornuftig indikator for udviklingen:

Jeg læser disse tal således, at benyttelsen af trykte tidsskrifter på det natur- og sundhedsvidenskabelige område er i frit fald. Udviklingen på det humanistisk/
Fig.2 - Benyttelse af trykte tidsskrifter ved NAT/SUND

2006: 126.608

2007: 84.347

2008: 68.293

sam-fundsvidenskabelige område går utvivlsomt langsommere, men den går i samme retning.

Lad os nu se på den elektroniske tidsskriftbenyttelse. Tallene er for hele KB og KUBIS-området. 
Fig.3 - Downloads af elektroniske tidsskrifter ved KB/KUBIS

\section{6: 2.319 .870}

2007: 2.819 .311

\section{8: 3.217 .801}

På grund af fusioner o.s.v. er det usikkert, hvor meget stigningen i disse tal skyldes stigning $\mathrm{i}$ benyttelsen og hvor meget der skyldes et større optællingsgrundlag. Om nogle år kan vi se udviklingen klarere. Vores egen fornemmelse er, at den reelle stigningstakt i disse år kun er på nogle procent om året, fordi vi er i et mættet og modent marked, men det er muligt, at etableringen af integrerede søgefaciliteter ved $\mathrm{KB} / \mathrm{KUBIS}$-området vil stimulere benyttelsen yderligere.

\subsubsection{Konklusion}

Under alle omstændigheder overgår benyttelsen af elektroniske tidsskrifter langt benyttelsen af trykte tidsskrifter, og den er i stadig - om end jævn - stigning, medens benyttelsen af trykte tidsskrifter er i stadigt og voldsomt fald. I løbet af 2 år vil Københavns Universitetsbibliotek stort set ikke have trykte natur- og sundhedsvidenskabelige tidsskriftabonnementer tilbage, og i løbet af 5 år heller ikke humanistiske/samfundsvidenskabelige. Det er ikke en spådom, men blot en tilkendegivelse af ledelsesmæssige beslutninger, som jeg personligt står over for at tage.

Det er i øvrigt ikke fordi vi er pionerer på området. For nogle år siden besøgte jeg biblioteket på Karolinska Instituttet i Stockholm, der er større end det sundhedsvidenskabelige universitets- og hospitalskompleks i København. Der fortalte chefen mig, at man allerede havde opgivet alle trykte tidsskriftabonnementer. Hvis der var nogle, der ville låne artikler, som ikke fandtes i elektronisk form, indlånte man dem bare. Det skete i øvrigt sjældent. Jeg blev faktisk stærkt forbløffet og følte mig som en bibliotekskustode med støv på.

I øvrigt begynder der nu at dukke oplysninger frem i rapportlitteraturen om, at forskerne synes, at nye artikler, der kun findes i trykt form, ikke er umagen værd, både fordi de er besværlige at gå til, men også fordi de så ikke kan være offentliggjort i prestigetidsskrifter!

Hvorom alting er: ved KUB - og jeg tror også ved de fleste store universitetsbiblioteker - er de trykte tidsskrifters tid ved at være forbi.

Det samme mener jeg gælder for referenceværkerne (leksika, ordbøger, statistik m.v.). Grundlæggende drejer det sig selvfølgelig om, hvem der gider gå hen på et bibliotek og finde faktuelle oplysninger, når man kan finde dem på sin egen pc.

\subsection{Bøger}

Også her ser vi separat på udbud, anskaffelse og benyttelse.

\subsubsection{Udbud}

Først par datoer: Den elektroniske bog skal være blevet "opfundet" i 1971 af Michael Hart, der gik videre med at grundlægge Project Gutenberg (Wikipedia 2009a). Den første kommercielle e-bog skal være blevet udgivet af Random House i 1981 (MyEBookDesign.com, 2009 og Wikipedia 2009b). I denne tidsalder er det allerede lang tid siden.

Ifølge en undersøgelse foretaget af den canadiske forskningsbibliotekssammen-slutning, Canadian Association of Research Libraries (CARL), var der $i$ august $2006 \mathrm{i}$ alt $135.492 \mathrm{e}$-bøger $\mathrm{i}$ udbud på det amerikanske marked, og væksten i udbuddet var på $20 \%$ om året (Owen et al., 2008). På det halvkommercielle marked er Google, Microsoft og Proquest i gang med store digitaliseringsprogrammer af ældre litteratur. Således har Proquest digitaliseret den ældre engelske litteratur indtil 1800, og man er nu startet på et tilsvarende program for den europæiske litteraturs vedkommende. Faktisk har firmaet lige indgået aftale med Det Kongelige Bibliotek om digitalisering af den danske litteratur indtil 1600-tallet.

Den nye Google-aftale (Google 2009) med den amerikanske stat og forlag rejser sådan set meget interessante problemstillinger mht offentlighedens frie adgang til litteratur. Men er man bekymret, skal man bare vente til 2025, for ifølge en ny science fiction roman, Rainbows End (Vinge 2006) bliver al trykt litteratur i det år redigitaliseret, fordi Google-digitaliseringen i århundredets begyndelse var for dårlig. Til 
gengæld bliver så al trykt litteratur kasseret - i hvert fald ved California University Library, hvor handlingen foregår!!

På den nylige $\mathrm{ACRL}^{3}$-konference i Seattle så jeg, at alle de store forlag nu førte sig massivt frem med deres e-bogsproduktion. De udstillinger, der var tilbage af trykte bøger, lugtede af gammel hat og små nicheforlag. På den rejse kunne jeg så også med egne øjne se, hvordan boghandlerne - der jo alle tilhørte kæder som Barnes \& Noble og Borders - havde stande, hvor de solgte e-bogslæseapparater.

En yngre medarbejder, der var med på turen, skulle absolut have tre af de nye Sony-apparater med hjem til sig og nogle kolleger - jeg tror, at det er ved at blive noget livsstilsnoget. Vi har alle hørt om Amazons tordnende succes med Kindle, og for nogle dage siden (23.3.) kunne man i selveste Berlingske Tidende [Allingstrup, 2009] læse en stort opsat artik el med overskriften: "e-Bogs krigen raser". I artiklen stod der blandt andet, at Sony og Amazon i disse dage udkæmper en udmattelseskamp om, hvem der kommer til at levere den vindende e-bogslæser. Amazon har den fordel, at den i forvejen er en inter- netbaseret boghandler, men Sony har til gengæld for nylig indgået aftale med Google om levering af en halv million elektroniske bøger til Sonys platform, og flere kommer til løbende.

KUB selv lancerede i øvrigt i går en udlånsordning baseret på 20 e-bogslæsere. Der var givet meddelelse om ordningen et par dage i forvejen, og bare en time efter åbningstidens begyndelse var de alle lånt ud og der var lige så mange reservationer. I Seattle hørte vi i øvrigt et foredrag om et universitetsbibliotek, der havde udlånt e-boglæseapparater til et helt hold studerende med deres semesterlitteratur indlæst.

Så, mine damer og herrer, jeg kan ikke selv være i tvivl: e-bogsmarkedet er i stærk bevægelse for tiden.

\subsubsection{Anskaffelser}

Det var udbudssiden. Hvordan med anskaffelserne? En Ebrary ${ }^{4}$-undersøgelse fra 2007 (McKiel 2007) viste, at $88 \%$ af de amerikanske biblioteker havde ebøger, og $45 \%$ mere end 10.000 . Men mon ikke alle biblioteker har dem i dag? KB/KUBIS har i hvert fald $i$ dag ca. 300.000 e-bøger. Til illustration viser jeg en figur med tal vedrørende anskaffelsen af bøger til KUB.

\section{Fig.4 - Anskaffelse af bøger til KUBIS/KB 2006-2009}

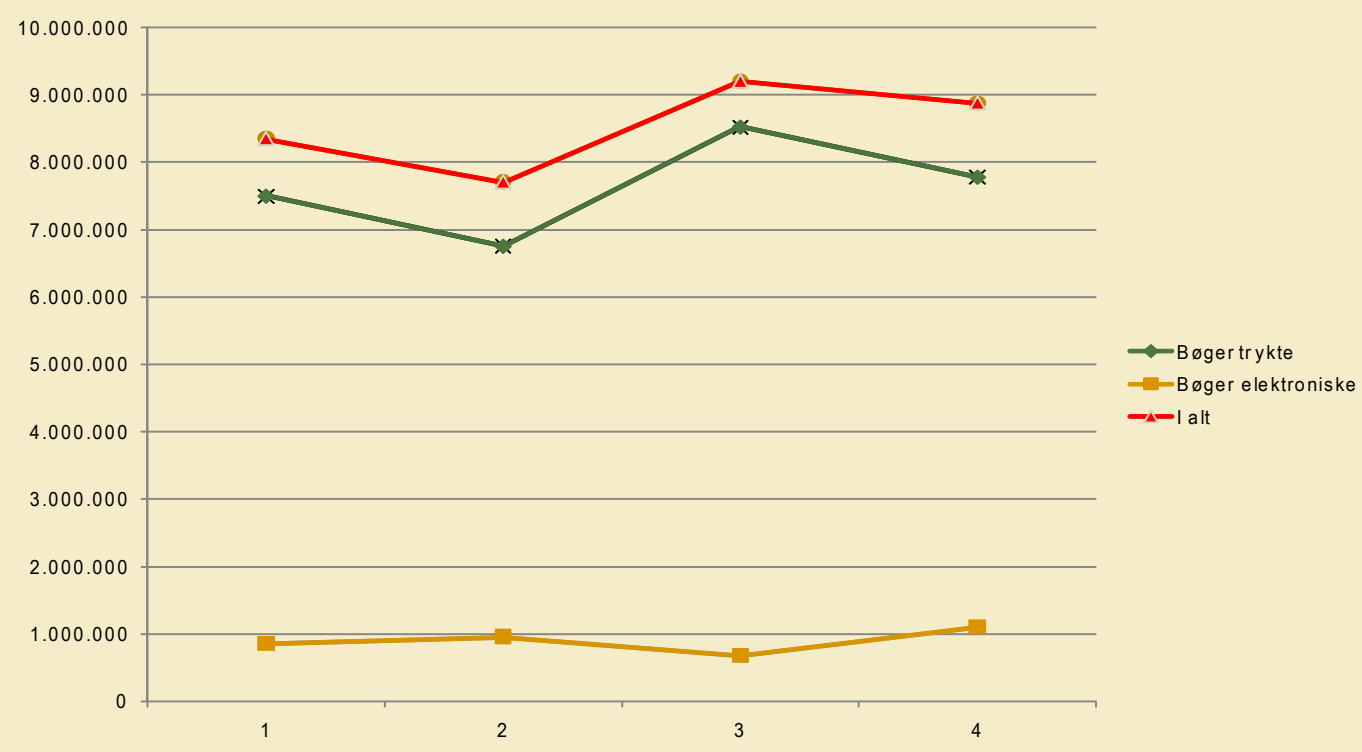


Som man ser, er billedet her det modsatte af tidsskrifterne. Vi bruger stadig langt størstedelen af budgettet på trykte bøger. Men vi bruger dog omkring 1 mio om året på e-bøger.

\subsubsection{Benyttelse}

Benyttelsen af e-bøger ved KB/KUBIS fremgår af fig. 5:

Flg.5 Benytelse af e-boger ved KB/KUBIS

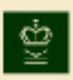

2007: $\quad 1.049 .930$

2008: $\quad 1.356 .865$

Heraf på fremmede servere:

2007: $\quad 93.661$

2008: $\quad 102.982$

Størstedelen af benyttelsen er af e-bøger på KBs egne servere, d.v.s. digitaliserede værker fra Nationalbiblioteket. Benyttelsen af universitetsbibliotekets e-bøger er mere beskeden. Den andrager nu 100.000 downloads om året og stiger p.t. med ca. $10 \%$ årligt. I betragtning af at vi taler om "rigtige", kommercielle e-bøger og ikke om working papers o.l. er dog også dette noget jeg ville have forsvoret for få år siden.

Interessant nok skal der være indikationer i det underliggende materiale af, at humanister faktisk er flittige benyttere af e-bøger. F.eks. blev der i 2008 foretaget 36.000 downloads fra e-bogssamlingen af engelsk litteratur indtil år 1800. Jeg gik faktisk kun med til anskaffelsen af denne samling af bibliotekspolitiske grunde, og jeg regnede bestemt ikke med at den ville blive benyttet nævneværdigt, så det er godt, jeg ikke væddede med at æde min egen hat.

Om vi skal bruge vore penge på at anskaffe e-bogssamlinger til naturvidenskab, ved jeg ikke rigtigt. Muligvis er naturvidenskab og sundhedsvidenskab så fikseret på tidsskrifter, at de hverken læser trykte eller elektroniske bøger. Vi prøver os forsigtigt frem.

\subsubsection{Konklusion}

Min konklusion m.h.t. e-bøger er, at udviklingen hidtil er gået langsomt, men til gengæld er der tegn på, at vi nu står foran et gennembrud på e-bogsområdet, ligesom vi gjorde det på e-tidsskriftområdet for ca. 10 år siden. Jeg tillader mig at citere en nylig undersøgelse fra CIBER $^{5}$ (2008), om informationsmønstret hos forskerne i fremtiden:

"E-bogens ubønhørlige fremmarch Uden for underholdningsmarkedet forventer vi, at salget af trykte bøger vil falde drastisk, efterhånden som elektroniske publiceringsinitiativer ... bliver en fast bestanddel af informationslandskabet.

Drevet af forbrugerefterspørgslen vil elektroniske bøger endelig blive det primære format for faglige lærebøger og videnskabelig litteratur." (CIBER, 2008, p. 26).

\subsection{Generel konklusion}

I år 2008 var den samlede benyttelse af KB/KUBIS digitale ressourcer ca. 6.4 millioner benyttelsesenheder. Til sammenligning var den trykte benyttelse kun 700.000 enheder. Den digitale benyttelse er stadig på vej op, den trykte er stadig på vej ned.

De trykte tidsskrifter er allerede ved at være et overstået kapitel. Med hensyn til bøgerne står vi foran et gennembrud for den elektroniske bog. Sådan tolker jeg i hvert fald tegnene på væggen. Så for mit eget vedkommende er jeg ikke i tvivl:

- Inden for 5 år er vi stort set ophørt med at købe trykte tidsskrifter.

- Jeg forestiller mig, at vi er ophørt med at købe trykte bøger inden for 20 år.

- Og inden for 30 år er den eksisterende trykte litteratur i vore samlinger erstattet af digitale udgaver via store digitaliseringsprogrammer.

\section{Hvor er lånerne på vej hen?}

Vi har nu behandlet spørgsmålet, om de trykte medier forsvinder. Vi skal nu så til spørgsmålet: hvor er lånerne på vej hen? Vi har endnu ikke lokale undersøgelser, men vil her i 2009 - muligvis sammen med universitetsbiblioteker i udlandet - gennemføre en undersøgelse af ph.d.-studerendes informationsadfærd. Ellers har vi en klar fornemmelse af, at en del af vore lånere bestiller litteratur fra os via bibliotek. $\mathrm{dk}$, fordi dette system dels forekommer enklere end vores tidligere Rex-system (som nu er afløst af en ny Rex baseret på Primo), og dels fordi bibliotek.dk gi- 
ver adgang til en langt større vidensamling end KB's eget katalog. Ellers er der mange undersøgelser om hele dette spørgsmål, og jeg skal her i dag henvise til fire af dem.

\subsection{OCLC-undersøgelse}

I 2005 udgav OCLC $^{6}$ et stort studie af Perceptions of Libraries and Information Resources (de Rosa et al., 2005), og i 2006 endnu en særlig delundersøgelse af de collegestuderendes biblioteksbenyttelse (de Rosa et al., 2006). De vigtigste konklusioner for vores vedkommende var følgende:

De amerikanske collegestuderende havde en højere grad af biblioteksbenyttelse end den generelle befolkning, men de forbandt primært biblioteket med trykte bøger, og brugte det fortrinsvis til studier. Undersøgelsens resultater bekræfter den undersøgelse Niels Ole Pors (2005) foretog under titlen "Studerende, Google og biblioteker". Det er med andre ord et generelt internationalt fænomen. Når de amerikanske studerende skulle begynde en informationssøgning startede $89 \%$ i søgemaskiner og kun $2 \%$ på en bibliotekshjemmeside. Den foretrukne søgemaskine var Google.

Søgemaskiner passer langt bedre med de studerendes livsstil end fysiske og virtuelle biblioteker: årsagen er den hurtige adgang til information, men endnu mere vigtigt var efter de studerendes opfattelse, at de får bedre kvalitet og kvantitet i søgemaskinebaserede søgninger end i bibliotekarstøttede søgninger. Biblioteket er således hverken det første eller det eneste sted, hvor de studerende søger information.

\subsection{CIBER-undersøgelse}

Sidste år udkom der en undersøgelse CIBER havde lavet for det engelske JISC [Joint Information Systems Committee]. Undersøgelsen har titlen: Information behaviour of the Researcher of the Future (Ciber, 2008). For vores vedkommende var de vigtigste konklusioner følgende:

\section{Fig.6 Aldersforskelle i måden at søge artikler på}
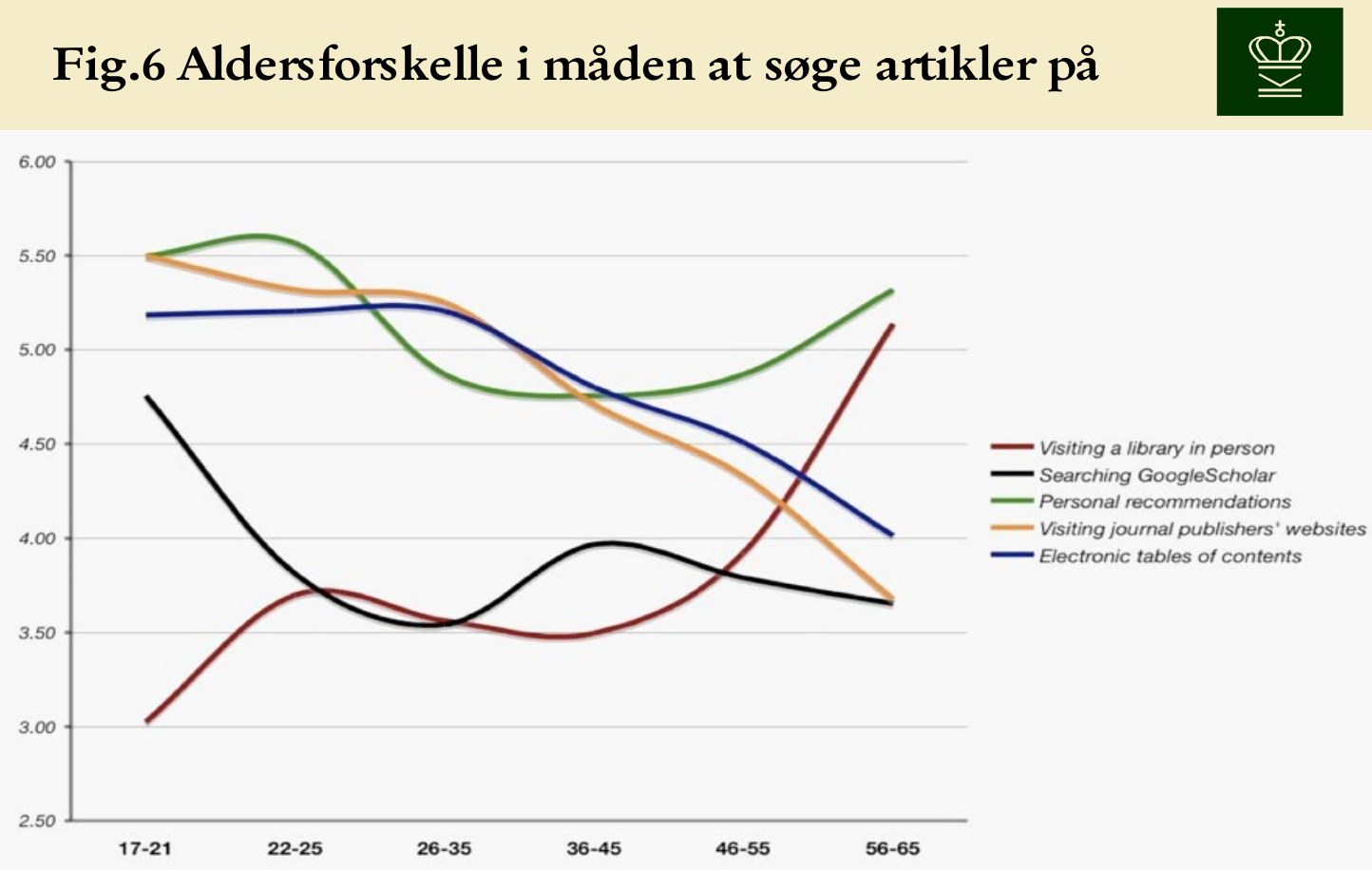
Både forskere og studerende er dybt præget af en udvikling med adgang:

- til enorme samlinger af digitale videnressourcer

- hele døgnet

- direkte uden om formidlersystemer (incl. biblioteker)

- $\quad$ via store, potente søgemaskiner

- $\quad$ og med ny læseadfærd (powerbrowsing, bouncing, squirelling)

Selvom nogle grundlæggende træk går igen mellem generationerne er der dog forskelle:

Man ser, at der er store forskelle vedrørende søgemåderne "Searching Google Scholar" og "Electronic tables of contents", som de unge brugte markant mere end de ældre. Omvendt var de ældre mere tilbøjelige til at besøge biblioteket fysisk.

\subsection{CURL ${ }^{7}$-undersøgelse}

En tredje undersøgelse er udført for den britiske sammenslutning af forskningsbiblioteker, CURL af Jubb \& Green (2007). De vigtigste konklusioner af denne undersøgelse er følgende:

Over de sidste 5 år er der sket et markant fald i antallet af forskere, der jævnligt besøger deres bibliotek. De fleste af dem bruger digitale søgeredskaber for at finde såvel digital som trykt litteratur. Jeg går ud fra at der ikke her menes online kataloger, ellers er det jo uinteressant. Af de digitale litteraturformer er langt den vigtigste de digitale tidsskrifter. $91 \%$ af forskerne mente, at den vigtigste faktor i biblioteksudvikling: øget adgang til information i digital form (91\%).

Man spurgte også forskerne, om de vigtigste opgaver for bibliotekarerne om fem år:

Den vigtigste opgave er efter forskernes bedømmelse at varetage samlinger af videnressource (som custodians - ikke et ord jeg selv ville vælge).

Interessant nok kommer administrationen af institutionelle repositories rimeligt højt.

Fagspecialistfunktionen kommer i midten, men lavere for så vidt angår naturvidenskab!
Administration af datasæt, som er et af de nyeste skud på stammen, kommer lavt - sammen med teknologisk specialistfunktion, men de er dog begge med og med interessante procenttal omkring de 30 .

Og så kan jeg ikke lade være med at nævne, at man også undersøgte forskernes kendskab til Open Access: Kun 1 ud af 10 kunne demonstrere at de vidste hvad Open Access er. Ærligt talt ikke imponerende, og - interessant - afhang deres viden i væsentlig grad af, om biblioteket aktivt havde gjort noget for at udbrede kendskabet dertil.

\subsection{Inger/Gardner-undersøgelse (2008)}

To private konsulenter, Simon Inger og Tracy Gardner (2008), udgav i efteråret en undersøgelse for en række forlag. Den har titlen: How Readers Navigate to Scholarly Content, og er en opfølgningsundersøgelse af en tidligere undersøgelse fra 2005. Jeg synes selv, den er ret spændende. Den rummer forskellige dårlige nyheder for bibliotekerne, men også en god. Et af spørgsmålene vedrører artikelsøgning om bestemte emner: hvor starter søgningen:

Som man ser, kommer bibliotekers hjemmesider på en 4-plads efter specialiserede bibliografiske databaser, generelle søgemaskiner, og forlagenes hjemmesider. Det er den ene dårlige nyhed. Mange af de fagspecifikke online bibliografier er dog nogle, som stilles til rådighed af bibliotekerne. At bibliotekernes hjemmesider kommer som nr. 4 er ikke overraskende, men jeg er til gengæld personligt overrasket over, at de generelle søgemaskiner kommer efter de specialiserede databaser: jeg ville have troet, det var de første. Jeg noterer mig derudover et fald i benyttelsen af bibliotekets hjemmeside fra 2005 til 2008. Det ser ud til at faldet sker til fordel for de generelle web-søgemaskiner, og tidspunktet falder sammen med introduktionen af Google Scholar i november 2004.

Undersøgelsen stillede også dette spørgsmål: når forskerne har referencen til en bestemt interessant artikel, hvordan søger de den så?

Her kommer de specialiserede bibliografiske database igen ind som nr. 1, men nu fulgt af bibliotekernes hjemmesider som nr. 2, lige efter tidsskriftets egen hjemmeside og først derefter de generelle søgemaskiner. Dog er der et fald i benyttelsen af bibliotekets hjemmeside fra 2005 til 2008. Det er den anden 
Fig. 7- Hvor starter emnesøgning?

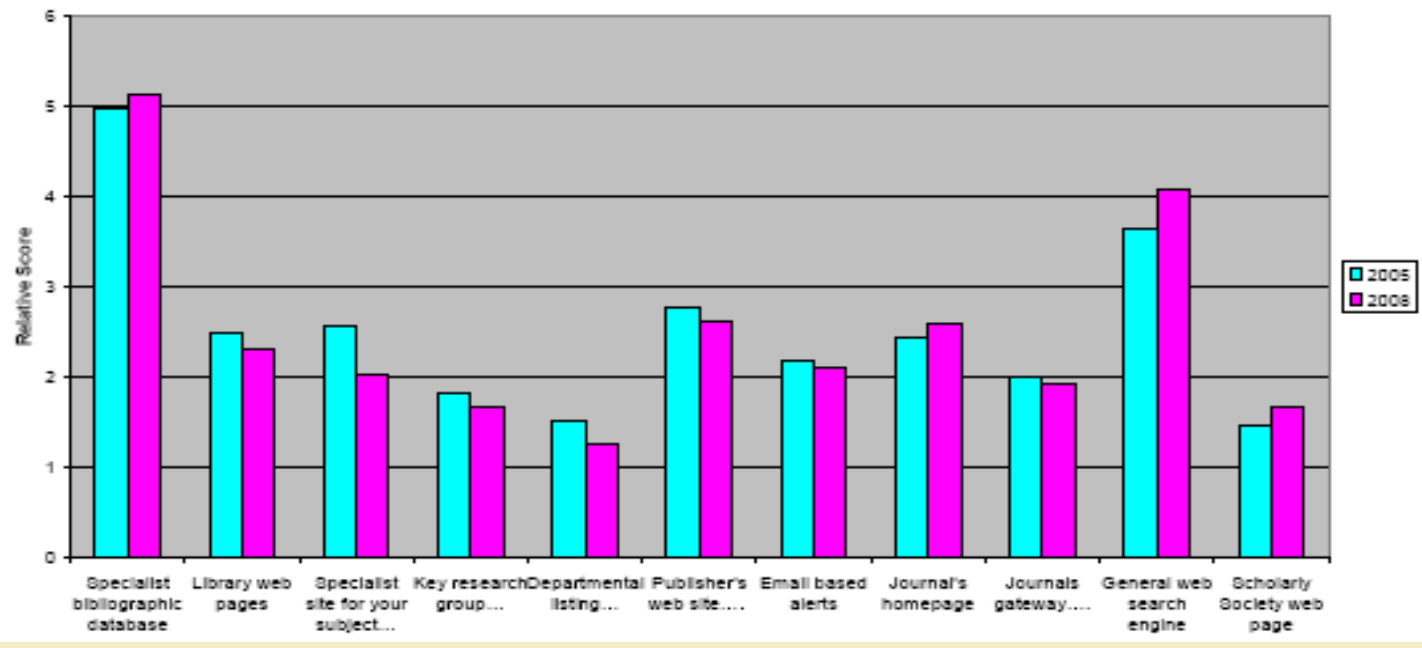

Fig.8 - Hvor starter søgning af en bestemt artikel?

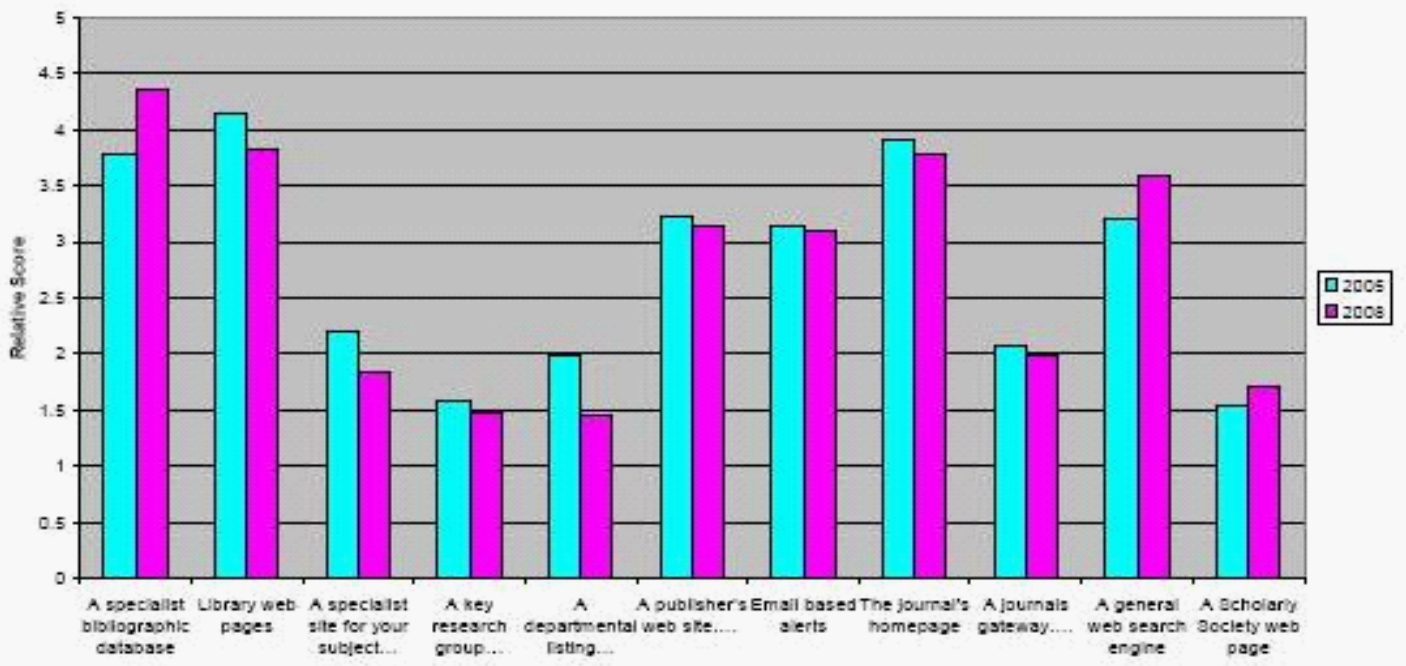


dårlige nyhed. Til gengæld var der et nyt spørgsmål i undersøgelsen vedr. forskerens opfattelse af om bibliotekets teknologi påvirkede forskerens navigation imod e-tidsskrifter: her svarede forskerne i undersøgelsen, at det skete oftere end i $95 \%$ af søgningerne

Vi har i forskningsbibliotekerne været noget nervøse for, om vore brugere forstår, at de e-ressourcer vi stiller til rådighed, faktisk stilles til rådighed af os. Det ved de åbenbart godt. Det er den gode nyhed. Forfatterne af undersøgelsen mener, at dette forhold skyldes bibliotekernes anvendelse af link servere (eller link resolvere), som gør det nemt for brugerne faktisk at få adgang til de e-artikler, de finder frem til på forskellige måder, men som de kun kan få fuldtekst adgang til, hvis deres eget bibliotek har licens.

\subsection{Konklusion}

Den hovedkonklusion, jeg selv som chef drager af disse undersøgelser er følgende:

Vore brugere finder information på mange måder, og bibliotekets katalog og hjemmeside er ikke deres primære søgeredskab. Vi konkurrerer både med de specialiserede bibliografiske systemer og med de generelle søgemaskiner, og vi er ved at tabe kampen. Det er dog et spørgsmål, om mulighed for søgning på artikelniveau i den nye kataloggeneration, vil få brugerne tilbage til katalogen som det primære søgeredskab. Jeg kan være noget i tvivl, men det bør bestemt forsøges - det er det vi gør med Summa og Primo, og som WorldCat gør med et tredje system.

Til gengæld står bibliotekerne stærkt med hensyn til at organisere brugernes adgang til deres egne licensbaserede ressourcer (via link resolvere m.v.) og det er glædeligt, at brugerne er opmærksomme på dette forhold.

\section{Overtager forlagene universitetsbibliotekernes funktion vedrørende litteraturforsyning?}

Jeg betragter absolut forlagene som en meget farlig konkurrent til forsknings-bibliotekerne. Det drejer sig om den frakoblingsproces (by-pass), som truer alle formidlersystemer i en informationsteknologisk udvikling, der fremmer den direkte kontakt mellem vidensskaberen og vidensforbrugeren, mellem forfat- teren og læseren. Både forlagene og bibliotekerne hører til den truede art af formidlingssystemer.

Det er allerede nu klart, at de store kommercielle forlag vil overtage lagringen af deres produktion på egne servere og give adgang hertil på forskellige vilkår. I den digitale informationsverden vil lagringsfunktionen baseret på trykte samlinger i universitetsbibliotekerne overgå til lagring af digitale samlinger hos de enkelte forlag selv. At der måske kan tænkes særlige samarbejdsformer mellem forlag og nationalbiblioteker vedrørende lagring af digitale værker, ændrer ikke billedet for universitetsbibliotekerne.

Forlagene vil også meget gerne have, at brugerne søger litteratur i deres egne søgesystemer. Nogle af forlagene har faktisk glimrende søgesystemer, som de oven i købet udvider til generelle søgesystemer, f.eks. Elseviers SCOPUS. Vi så i Inger/Gardner-undersøgelsen, at forlagenes hjemmeside kun var det tredjemest anvendte udgangspunkt for emnesøgninger. Det er stadig væk imponerende, og skræmmende for bibliotekerne, der kom på 4-pladsen.

Grundlæggende tror jeg dog, at forlagenes bestræbelser på at overtage søgefunktionen vil støde på, at de færreste lånere kan klare sig med ét forlags produktion. Lånerne vil derfor naturligt foretrække integrerede søgesystemer, der giver bred adgang til litteraturen på tværs af forlagene.

For bibliotekerne er den største fare ikke, at lagringen af information sker uden for biblioteket. Den største fare består $i$, at forlagene finder ud af en basalt ny forretningsmodel baseret på en kombination af

- pay per view (eller en anden brugervenlig ordning)

- ultrabillige downloadspriser (f.eks. 25 øre pr artikel), og

- direkte adgang fra fagspecifikke bibliografier og generelle søgemaskiner

Biblioteksfunktionen ved KU koster i dag ca 250 millioner årligt. Heri er inkluderet 100 mio. kr. til overheadudgifter, bl.a. dyre bygnings- og lokaleudgifter. Af de 250 mio. går ca. 50 mio.kr. til at betale for videnressourcer. 
Hvis forlagene laver superbillig, direkte adgang til deres ressourcer, kunne universiteterne godt til sin tid finde på, at spare biblioteket helt eller delvist væk og anvende en meget stor del af eller alle de 250 mio. kr. til direkte køb af videnressourcer. Så hvis jeg var en ung bibliotekschef på 40 år, så ville jeg være bange, meget bange for hvad forlagene vil gøre. "Heldigvis" er der tegn på, at forlagenes principielle grådighed vil forhindre dem i at se fordelene ved en superbillig forretningsmodel. Tværtimod vil de prøve at tjene så mange flere penge, at der er rimelig risiko for, at regeringerne - hvis ikke forskerne selv - vågner op og gennemtvinger grøn Open Acces, således som det er ved at ske i USA, Canada og Australien. Så er det forlagene, der ryger.

\section{Kan universitetsbibliotekernes andre funktio- ner sikre vores overlevelse som serviceorganisa- tion?}

Vi går nu over til det sidste spørgsmål: Kan de andre forskningsbiblioteksfunktioner sikre vores overlevelse som serviceorganisation? Først skal vi se på: hvilke andre funktioner vil der være. M.a.o.: Hvilke hovedfunktioner har universitetsbibliotekerne i dag udover dette at anskaffe videnressourcer og stille dem til rådighed for brugerne? Vi vil se på følgende:

\section{Søgesystemer}

2. Studiemiljø

3. Personlig service og brugerundervisning

4. Forskningsregistrering

5. Repositories

6. Dataforvaltning (e-science)

7. Digitalisering af universiteters egne videnressourcer

\subsection{Sogesystemer}

Jeg har allerede kommenteret, at bibliotekernes hidtidige søgesystemer er ved at tabe kampen til de store fagspecifikke systemer og til de globale søgesystemer.

Det er et åbent spørgsmål, om en ny generation af bibliotekssøgesystemer - Med integreret artikelsøgning - kan vende denne udvikling. For selv om de kan blive meget mere smarte, er det vanskeligt for dem at hamle op med globale systemer. Lånerne vil også have kvantitet og er ligeglade med enkelte biblioteker.
Personligt tror jeg, at det eneste reelle biblioteksalternativ til de andre søgesystemer er en global, supersmart katalog med integreret søgning af artikler og alt muligt andet smart. OG: jeg ville sætte mine penge på WorldCat - samarbejdet med Google og den seneste tekniske udvikling af systemet er ikke matchet af andre leverandører. Individuelle bibliotekskataloger tror jeg ikke på som fremtidsløsning - redundante data er dyre.

\subsection{Studiemiljø}

Det er vores indryk at i den seneste generation er de studerende vendt tilbage til bibliotekernes læsesale. Vil de også være der om en generation? Jeg tror det selv, fordi min egen erfaring, det blik jeg kaster på den kultur der omgiver mig, siger, at den moderne informationsteknologi ikke får folk til at isolere sig i elektroniske miljøer, tværtimod. Cafekulturen er et produkt af mobiltelefonen. Vi kommunikerer for at mødes. En ung journalist i min udvidede familie tog for nogle år siden overbygning på IT-universitetet og lavede som afgangsgruppeopgave et mobiltelefonsystem, der kunne lokalisere hvem af ens venner, der var i fysisk nærhed. Så kunne de jo lige mødes på en café.

Bibliotekernes studiemiljø er udtryk for en fællesskabskultur, en samværskultur, som jeg tror, vil blive mere og mere udtalt, jo mere informationsteknologien udvikler sig, den er måske informationsteknologiens modbalance.

Så personligt tror jeg som bibliotekschef, at dette led i universitetsbibliotekernes service vil vise sig modstandsdygtigt over de informationsteknologiske forandringer.

\subsection{Personlig service og brugerundervisning}

Også dette er en serviceform, som jeg brænder for. Hvordan den skal indrettes, ved jeg ikke - der sker så mange ting, og der udvikles hele tiden nye kommunikations-former. Og for så vidt angår brugerundervisning er jeg sikker på, at den skal skifte ham radikalt. Men det er min klippefaste opfattelse, at en af de søjler, den fremtidige biblioteksfunktion skal hvile på, er personlig service, incl. face-to-face møde mellem bruger og biblioteksmedarbejder. Det er ikke bare et spørgsmål om at vurdere brugernes fremtidige behov, men også et ideologisk spørgsmål, d.v.s. 
et spørgsmål om hvordan vi gerne fra vores side vil være med til at præge fremtidens servicesamfund.

Selv vil jeg ikke have et afpersonaliseret servicesamfund baseret udelukkende på robotter og kunstige intelligenser - heller ikke med menneskelige ansigter. Så her synes jeg, at vi fra biblioteksside skal slås for at være der og for at forme fremtiden, og ikke bare underkaste os den.

\subsection{Forskningsregistrering}

For en 15 års tid siden begyndte de første danske universitetsbiblioteker at registrere/katalogisere forskningspublikationer ved deres universitet $\left(\mathrm{CBS}^{8} /\right.$ DTU). Ved CBS skete det som et led i afprøvning af grænserne for biblioteksfunktionen OG som udtryk for en politik om at være leveringsdygtig med alle CBS' forsknings-publikationer. Sidenhen udviklede tingene sig ved at:

- der kom en ny lov der ophøjede forskningsformidling til den tredje grundlæggende universitetsopgave

- de øvrige universitetsbiblioteker kom med

- PURE-systemet ${ }^{9}$ blev indført stort set overalt, og senest er

- forskningsproduktion lagt til grund for bevillingstildeling

I dag er den generelle situation den, at de universiteter, der har egne universitets-biblioteker, har overladt forskningsregistreringen til disse. Kun Århus og København har placeret forskningsregistreringen uden for universitetsbiblioteket, om end mange bibliotekarer rundt omkring i systemet er involveret på den ene eller den anden måde.

Jeg vil tro, at KB/KUBIS og Statsbiblioteket på et eller andet tidspunkt får ansvar for ÅUs og KUs forskningsregistrering. Og under alle omstændigheder bedømmer jeg det som en særdeles vigtig "aktie i fremtiden", at UB på denne måde har overtaget en ny og vigtig, funktion for universitetet, og en som er i helt naturlig forlængelse af bibliotekernes klassiske opgave.

\subsection{Repositories}

I vore tider er det helt naturligt, at en institution opbygger et fuldtekst repository over alle "egne" publi- kationer eller at der etableres et repository for et fags eller fagområdes publikationer. Universitetsbiblioteker er involveret i udvikling og drift af begge former for repository. Flere danske biblioteker udvikler lokale institutionelle repositories i tilknytning til deres forskningsregistreringsopgaver. Og for så vidt angår internationale fagspecifikke repositories er det store, strålende eksempel arXiv, der er repository for astronomi og beslægtede videnskaber, og som i dag drives af Cornell University Library. Der er bestemt problemer med begge former for repository.

For de institutionelle repositories er der

- Forskerambivalens p.g.a.:

- pres på meritering ved publicering $\mathrm{i}$ internationale tidsskrifter

- ønske om peer review, som er vanskelig i egne institutionsrepositories, og

- institutionsangst for lavprestige lokalpublicering

Med hensyn til de fagspecifikke repositories er der problemer med

- forlagenes angst for at blive koblet fra videnskabelig publicering

- peer review-problematikken igen, og hele

- spørgsmålet om Open Access

Men arXiv er ikke desto mindre en kæmpesucces, som burde danne skole. Personligt tillægger jeg det afgørende betydning for den fremtidige udvikling af universitets-bibliotekerne, at de får en væsentlig funktion i forbindelse med udvikling og drift af repositories først og fremmest af institutionelle, men også af fagspecifikke repositories.

\subsection{Dataforvaltning}

Udviklingen af det videnskabelige publikationssystem er nu ved at bevæge sig videre ud over den afsluttende forskningspublikation til hele det datagrundlag, der ligger nede under publikationen (forsøgsprotokoller, observationsdata, statistikmateriale, computerprogrammer). Det kaldes forskelligt (bl. a. e-science), men en vigtig funktion er f.eks. inden for den eksperimentbaserede forskning at gøre det muligt for andre forskere at kunne rekonstruere og dermed validere et forsøg og verificere resultaterne. Også her er det umådeligt interessant, om UB kan få 
en central funktion i udvikling og drift af systemer til bevaring og formidling af forskningsdata.

For nylig var min direktør, Erland Kolding Nielsen, ved at få morgenkrydderen galt i halsen, da han i sin avis (Berlingske Tidende) læste en artikel om NASAs nye mission til udforskning af universet [Dreehsen, 2009]. Der stod nemlig i artiklen, at NASA sender alle observationer fra Kepler-satellitten direkte til Det Kongelige Bibliotek i København. Der var det lille problem, at man ikke havde nået at orientere direktionen om dette projekt. Det går hurtigt på Det Kongelige Bibliotek (nu med Kepler-data!)!! ... og det er selvfølgelig en super chance, at et bibliotek får ansvaret for at bevare disse data.

\subsection{Digitalisering af universiteters egne videnres- sourcer}

I en nylig evaluering af Københavns Universitetsbibliotek udtalte evaluatorerne blandt andet, at biblioteket burde gå ind i digitalisering og formidling af videnressourcer fra universitetet, f.eks. fra museale og arkivale samlinger rundt omkring på fakulteter og institutter. Det er vi så ved at begynde på. Det første projekt er digitalisering af en historisk samling af havetegninger fra LIFE-fakultetet. Senere vil der formentlig komme en papyrussamling fra et af institutterne på HUM-fakultetet samt teatergruppen Solvognens arkiv, der i dag ligger på Institut for Kunst og Kulturvidenskab. Hvor dette skal bære hen, ved jeg ikke, men vi har umiddelbart meget positive reaktioner fra universitetsside over for bibliotekssidens forslag om at gøre noget i denne retning.

Fælles for hele området forskningsregistrering, repositories, dataforvaltning og digitalisering af universitetsressourcer er, at det kræver betydelige ressourcer både til udvikling og drift. Det er usandsynligt, at vi får alle de nødvendige midler tilført, så hvis ikke andre parter skal sætte sig på disse opgaver, skal vi formentlig formå selv at gennemføre de nødvendige omprioriteringer.

\subsection{Kan disse funktioner sikre vores overlevelse?}

Jeg har nu gennemgået en række funktioner og opgaver, som ligger ud over selve dette at anskaffe videnressourcer og gøre dem tilgængelige for universitetet. Jeg stiller så spørgsmålet, om disse opgaver er nok til at sikre UBs overlevelse som serviceorganisation, når alle videnressourcer er blevet digitale og der ikke længere er fysiske samlinger i UB.

Jeg tror selv, at det afgørende spørgsmål bliver, om det stadig er bibliotekets rolle at organisere og tilgængeliggøre elektroniske videnressourcer for universitetet eller ej. Denne opgave vil formentlig under alle omstændigheder være reduceret væsentligt i forhold til i dag, fordi andre stærke aktører er på banen (Google og Googles efterfølgere f.eks.).

Grundlæggende er det min opfattelse, at

- Trykt litteratur definerer det klassiske bibliotek, medens

- Elektronisk litteratur definerer det digitale bibliotek.

Hvis biblioteket hverken har trykt eller digital litteratur, er det slut med biblioteket, uanset hvilke opgaver, biblioteket ellers kan have eller få. Uden videnressourcer, intet bibliotek. I denne optik er det derfor det afgørende strategiske krav, at universitetsbibliotekerne skal kæmpe for at bevare deres opgave med at forsyne universitetet med elektroniske videnressourcer. De fire hovedopgaver, som jeg ser som fremtiden for universitetsbiblioteket, er:

- Først og vigtigst: at organisere en stor samling af internationale elektroniske videnressourcer til brug for universitetet

- At levere personlig informationsservice i alle relevante former

- At stille et tiltrækkende studiemiljø til rådighed for de studerende

- At organisere universitetets egne digitale ressourcer, både forskningsproduktionen og andre digitale ressourcer, og at gøre dem tilgængelige via lokale såvel som internationale formidlingssystemer

Min samlede generelle konklusion er følgende: de trykte tidsskrifter og bøger forsvinder ud af universitetsbibliotekerne i løbet af den kommende generation. Hvis det lykkes os at hage os fast til formidlingen af digitale videnressourcer til universitetet kan vi overleve som institution.

Hvis ikke forsvinder vi - som en værdifuld institution, der har tjent civilisationen vel i århundreder, men hvis tid er omme, fordi andre løsninger tjener en 
ny tid bedre. Ville det så være et problem? Efter min egen opfattelse nej: for, kære kolleger, for os drejer det sig IKKE om institutioner og formater - d.v.s. biblioteker og bøger, men om formidling af videnskabelig og faglig information til - og fra - universitetet.

Men selvfølgelig skal vi slås for at være der i fremtiden. Og der er gode muligheder, hvis vi formår at fokusere på det, der skal bære os igennem til en ny tidsalder, den digitale tidsalders bibliotek.

\section{Noter}

1. Lettere redigeret version af foredrag holdt på Danmarks Biblioteksskoles temadag: "Visioner for Forskningsbibliotekernes Fremtid" 2. april 2009

2. KUBIS er akronym for en samarbejdsorganisation mellem Det kongelige Bibliotek (KB) og Københavns Universitet etableret 2007: "Københavns Universitets Biblioteks- og Informationsservice".

3. The Association of College and Research Libraries, en underafdeling af American Library Association

4. Ebrary er betegnelsen for en virksomhed (ebrary, Inc.) og en kommerciel e-bogsbase, som flere danske forskningsbiblioteker giver adgang til.

5. CIBER (Centre for Information Behaviour and the Evaluation of Research) findes i Department of Information Studies, University College London. Hjemmeside: http://www.ucl.ac.uk/infostudies/research/ciber/

6. OCLC (Online Computer Library Center, Inc.; oprindeligt Ohio College Library Center) er en ikkekommerciel organization, der arbejder for at skabe bedre adgang til information og reducere udgifter til biblioteksdrift.

7. Consortium of University Research Libraries (CURL), Storbritannien.

8. $\mathrm{CBS}=$ Copenhagen Business School; DTU $=$ Danmarks Tekniske Universitet

9. PURE er et system til forskningsregistrering udviklet af firmaet Atira.

\section{Referencer}

Allingstrup, M (2009). E-Bogs krigen raser. Berlingske Tidende 23.03.2009, Business s. 12. Tilgået 2009-10-09 fra: http://www.business.dk/article/20090322/ittele/703220062/

Dreehsen, LL (2009). NASA: Jagten sættes ind på Jordens tvilling, Berlingske Tidende 7. marts 2009, 1. sektion, s.6, Tilgået 2009-10-09 fra: http://www. berlingske.dk/article/20090307/viden/703060102/

CIBER (2008). The Information behavior of the researcher of the future. Executive Summary. A ciber briefing paper. Tilgået 2009-10-10 fra: http://www. ucl.ac.uk/infostudies/research/ciber/downloads/ ggexecutive.pdf (Rapportens enkelte dele kan downloades fra: http://www.ucl.ac.uk/infostudies/research/ciber/downloads/ )

De Rosa, C, Cantrell, J, Cellentani, D, Hawk, J, Jenkins, L \& Wilson, A (2005). Perceptions of Libraries and Information Resources. A Report to the OCLC Membership. Dublin, Ohio USA: OCLC Online Computer Library Center, Inc. Tilgået 2009-10-10 fra: http://www.oclc.org/reports/pdfs/Percept_all.pdf

De Rosa, C, Cantrell, J, Hawk, J \& Wilson, A (2006). College Students' Perceptions of Libraries and Information Resources. A Report to the OCLC Membership. A Companion Piece to Perceptions of Libraries and Information Resources. Dublin, Ohio USA: OCLC Online Computer Library Center, Inc. Tilgået 2009-10-10 fra: http://www.oclc.org/reports/ pdfs/studentperceptions.pdf

Google Books (2009). Google Books Settlement Agreement. Tilgået 2009-06-25 fra: http://books.google. com/googlebooks/agreement/

Inger, S \& Gardner, T (2008). How Readers Navigate to Scholarly Content. Comparing the changing user behaviour between 2005 and 2008 and its impact on publisher web site design and function. Abingdon, UK: Simon Inger Consulting \& Tracy Gardner Marketing. Tilgået 2009-10-10 fra: http:// www.sic.ox14.com/howreadersnavigatetoscholarlycontent.pdf

Jubb, M \& Green, R (2007). Researchers Use of Academic Libraries and their Services. A report 
commissioned by the Research Information Network and the Consortium of research libraries. London: Research Information Network and Consortium of curl Research Libraries in the British Isles. Hentet 2009-10-09 fra: http://eprints.ecs.soton. ac.uk/13868/1/libraries-report-2007.pdf

McKiel, AW (2007). ebrary's Global eBook Survey, ebrary. Tilgået 2009-10-10 fra: , http://www.ebrary. com/corp/collateral/en/Survey/ebrary_eBook_survey_2007.pdf

MyEBookDesign.com. (2009). History [of the ebook]. Tilgået 2009-10-09 fra: http://www.myebookdesign.com/History-Of-E-Book-Design.aspx

Owen, V, Tiessen, R, Weir L, DesRoches, R, \& Noel, W (2008). E-Books in Research Libraries: Issues of Access \& Use. Ottawa, Ontario: Canadian Association of Research Libraries (CARL), Task Group on E-Books. Tilgået 2009-10-09 fra: http://www.carl-abrc.ca/projects/copyright/pdf/

CARL\%20E-Book\%20Report-e.doc

Pors, Niels Ole (2005). Studerende, Google og biblioteker: En undersøgelse af 1694 studerendes brug af biblioteker og informationsressourcer. København: Biblioteksstyrelsen og Danmarks Biblioteksskole. (Elektronisk publikation). http://www.bs.dk/publikationer/andre/studerende/pdf/studerende_google_og biblioteker.pdf

Vinge, Vernor (2006). Rainbows End. New York: Tor Books.

Wikipedia. The free encyclopedia. (2009a). Michael S. Hart. Tilgået 24/6-2009 fra: http://en.wikipedia. org/wiki/Michael S. Hart

Wikipedia. The free encyclopedia. (2009b). E-book. Tilgået 2009-10-09 fra: http://en.wikipedia.org/wiki/ E-book 